\title{
Grammar and Gender: A Comparative Study of the Integration and Organisation of Meanings in Selected Male and Female-authored Proseworks
}

\author{
Toyese Najeem Dahunsi (Corresponding author) \\ General Studies Department, Federal Polytechnic, Ile-Oluji, Ondo-Ipetujesa Road, Ondo State, Nigeria \\ E-mail: deoladahunsi@gmail.com
}

Received: 20-07-2016

Published: 02-01-2017
Accepted: 01-10-2016

doi:10.7575/aiac.ijalel.v.6n.1p.275
Advance Access Published: November 2016

URL: http://dx.doi.org/10.7575/aiac.ijalel.v.6n.1p.275

\begin{abstract}
Studies have established gender-based variations in human's use of language, particularly in the areas of grammar and lexis. This study investigated language use in prose-works involving male and female writers, aimed at finding out whether there were grammar related variations in the use of language by the selected male and female writers. The framework adopted for analysis was the Hallidayan notion of Clause Complexes and Embedded Clauses and how writers made conscious choices from the grammar of logical meaning in their different narratives. Five male-authored and five female-authored prose-works were selected for the study. A part of each prose-work containing fifty (50) consecutive sentences was randomly excised and analysed into clause simplexes, clause complexes and embedded clauses, and the frequencies of these clause types were determined. The result clearly showed that the male authors had higher frequencies of clause complexes than simplexes; whereas the female writers had lower frequencies of complexes but higher frequencies of simplexes. It also showed higher frequencies of embedded clauses in male-authored texts than in female-authored ones. The results therefore suggested that narratives of male writers tend to be more syntactically complex (because of higher frequencies of clustered clauses and varying functional and semantic relationships among component clauses) and semantically complex (because of a much tighter integration of meanings through clause clustering and embedding). The narratives of female writers, on the other hand, tend to be syntactically and semantically simple (with higher use of simplexes, but less use of complexes and embedded clauses).
\end{abstract}

Keywords: Grammar, gender, clause complexes, clause simplexes, embedded clauses.

\section{Introduction}

Language, as Chomsky (2001: p.2) notes, 'appears to be a true species property, unique to human species in its essentials'. Humans use language for various purposes prominent among which is to communicate feelings, messages, opinions, requests or information to one another. They use language almost per minute, as most of their daily activities (greeting, buying, selling, singing, worshiping, instructing, explaining, negotiating, warning, offering, accepting, rejecting, appreciating etc.) are carried out using language. Language is therefore one of the windows through which the human nature can, and has often been studied.

Issues relating gender have a long history. As Eckert and McConnel (2003: p.9) note, 'We are surrounded by gender lore from the time we are very small', noting that gender issues are ever-present in conversation, humor and conflict, and 'it is called upon to explain everything from driving styles to food preferences'. Issues and ideas about gender have for a long time been overwhelming and almost taken to be natural, specifically portraying the females with some negativity but males with some positivity pervasively. The acceptance or rejection of some of these commonplace genderised beliefs and perceptions led to a consistently increasing body of research on gender, some studies confirming differences, some claiming equality (both with scholarly evidence). Such research efforts have been multidisciplinary, ranging from psychology to sociology, and from biological sciences to linguistics, depending on the focus of research. Linguistics, among other numerous areas of coverage and application, has been concerned with the interface of gender and language use with specific focus on the relationship between the structure of a language and the use of that language by women and men who speak it (Farinde, 2009). As Cameron (1985) notes, gender and language research was for many years based on the search for correlations between linguistic units and social categories of speakers, and later shifted to analysis of the gendered significance of ongoing discourse.

Earliest studies on language and gender date back to the 70's with the novel work of the American Feminist Linguist Robin Lakoff in 1975 as foundation. In the study, Lakoff (1975) reported marked differences in the use of language by both men and women, with the averments (Farinde, 2009: p.24) that women 'use many linguistic forms which weaken or mitigate the force of their utterance'. Other studies on language and gender have developed from this, and interests have continued to increase in this area of linguistic scholarship. Studies in language and gender have adopted two main approaches: one that views language as constructing gender inequality with the male seen as dominant over the female, 
Zimmerman and West (1975), O'Barr and Atkins (1978), West, Lazar and Kramarae (1997), Kendal and Tanen (2003). Such studies have also been based on power relations and asymmetry between the male and the female, with the notion that 'women's interests are systematically subordinated to men's', (Farinde, 2009: p.27).

The other approach is the difference approach, where scholars, rather than view gender variations in language use as indexing power asymmetry and dominance, see such variations as context-based, as Farinde (2009: p.29), citing Holmes (1984) argues, 'the same linguistic forms, such as tag question, may serve a variety of functions, depending on the context of its use, to whom one is speaking, with what kind of intonation, the formality of the speech context and the type of discourse'. Studies that have adopted this approach include Cameron (1985), Cameron (1988), Tanen (1994), Tanen (2003), Holmes (1990) etc. There have been heightened criticisms of this approach, with different scholars coming up with different arguments of invalidation. Crawford (1995: p.4) argued that difference is fluctuating and variable, and that
...highly publicized sex differences turn out to be limited to particular subgroups
or not replicable in further studies. Such differences have some quality that
seems inconsistent with using them as fundamentals of human nature (Unger, 1992;
Unger and Crawford, 1992) and even when a sex difference is defined in ways
that are quite specific and quantifiable, its meaning is not socially neutral.
Rather, the meaning of a sex difference is the product of social negotiation; it is
culturally produced. And, it is produced in the context of a pre-existing system
of meanings in which difference is polarized.

(Crawford, 1995: p.4)

\subsection{Systemic Functional Grammar and organization of meanings in clauses}

Systemic Functional Grammar (SFG) is a theoretical postulation and analytical framework of Michael Alexander Kirkwood Halliday, a British-born Australian linguist, which became prominent and more novel after his publication of An Introduction to Functional Grammar in 1985. Halliday (1985: p.xiv) describes the theory as one "by which a language, or any other semiotic system, is interpreted as networks of interlocking options' and where 'whatever is chosen in one system becomes the way into a set of choices in another'. SFG deals largely with the structural organization of English clauses. Yet, Halliday's interest is substantially on the meanings of language in use in the 'textual processes of social life', or 'the sociosemantics of texts', (Eggins, 2004: p.2). Halliday (1994: p.xv) explains that the aim of the Grammar 'has been to construct a grammar for purposes of text analysis: one that would make it possible to say sensible and useful things about any text, spoken or written, in modern English'.

Central to SFG is the focus on the clause as the basic unit of analysis, with the postulation that the clause is multifunctional, having three types of meanings expressed in it. These three types of meaning are ideational, elsewhere referred to as experiential, (Thompson, 2004), interpersonal and textual, the trio technically described by Halliday (1985), Halliday and Matthiessen (2004) and Halliday and Matthiessen (2014) as the metafunctions of language. Seen this way, Halliday and Matthiessen (2004: p.361) describe the English clause as a 'composite affair', saying it is 'a combination of three different structures deriving from distinct functional components.

Halliday and Matthiessen (2014) posit that in narrative texts, the flow of events is construed as series of episodes. Each episode is developed step-by-step as sequences of figures; and the semantic sequence of figures is realized by a series of what they call 'clause complexes', Halliday and Matthiessen (2014: p.428). This means that humans organize and integrate meanings into clauses by combining different grammatical and semantic units; each clause usually forming a figure in the narrative episode; and the figures being linked together 'by means of temporal relators' (429). In SFG the sentence is recognized as the 'highest graphological unit of punctuation', and in the written text, the sentence is 'treated as one clause complex, with the simple (one clause) one clause sentence as the limiting case' (p. 438). The integration of meanings in clauses therefore has to do with the syntactic and semantic composition of clauses, how clauses have been linked together to form narrative episodes, and the kind of relationships that exist among linked clauses in the narrative. It is from this background that Halliday and Matthiessen (2014) came up with the notion of clause complexes, simplexes and embedded clauses.

\subsection{The notions of clause complexes, simplexes and embedded clauses}

SFG sees texts and talks as comprising clauses, each clause being made up of what comes below it in the grammatical rank-scale (groups and phrases), and each being linked together either paratactically (linking of two or more clauses of equal functional and semantic status together by coordination) or hypotactically (linking of two or more clauses of unequal functional and semantic status together by subordination) depending on the 'degree of interdependency', Halliday and Matthiessen (2004: p.438). SFG describes the linking of clauses above together by means of logicosemantic relation to form one clause complex. A clause complex is therefore made of at least two clauses linked together in texts. Eggins (2004: p.255) describes a clause complex as 'the grammatical and semantic unit formed when two or more clauses are linked together in certain systematic and meaningful ways'. A clause that stands independently and conveys complete semantic sense e.g. I am hungry is, however, referred to as a simplex. The same simplex I am 
hungry can be expanded and extended by adding because I do not have money to form the clause complex I am hungry because I do not have money. Halliday and Matthiessen (2004) further posit that semantically, 'the effect of combining clauses into a clause complex is one of tighter integration in meaning, averring further that 'the sequences that are realized grammatically in a clause complex are construed as being subsequences within the total sequence that make up a whole episode in a narrative' (p. 438).

Part of the logicosemantic resources available to users of language, particularly English, is the system of the clause complex from which choices are made by writers and speakers between clause complexes and simplexes on one hand, and from the different types of clause complexes available on the other. Eggins (2004: p.256) argues that where there is choice, there is meaning; and the reasons for certain choices can only be understood with recourse to the system of the clause complex presented in Fig. 1.

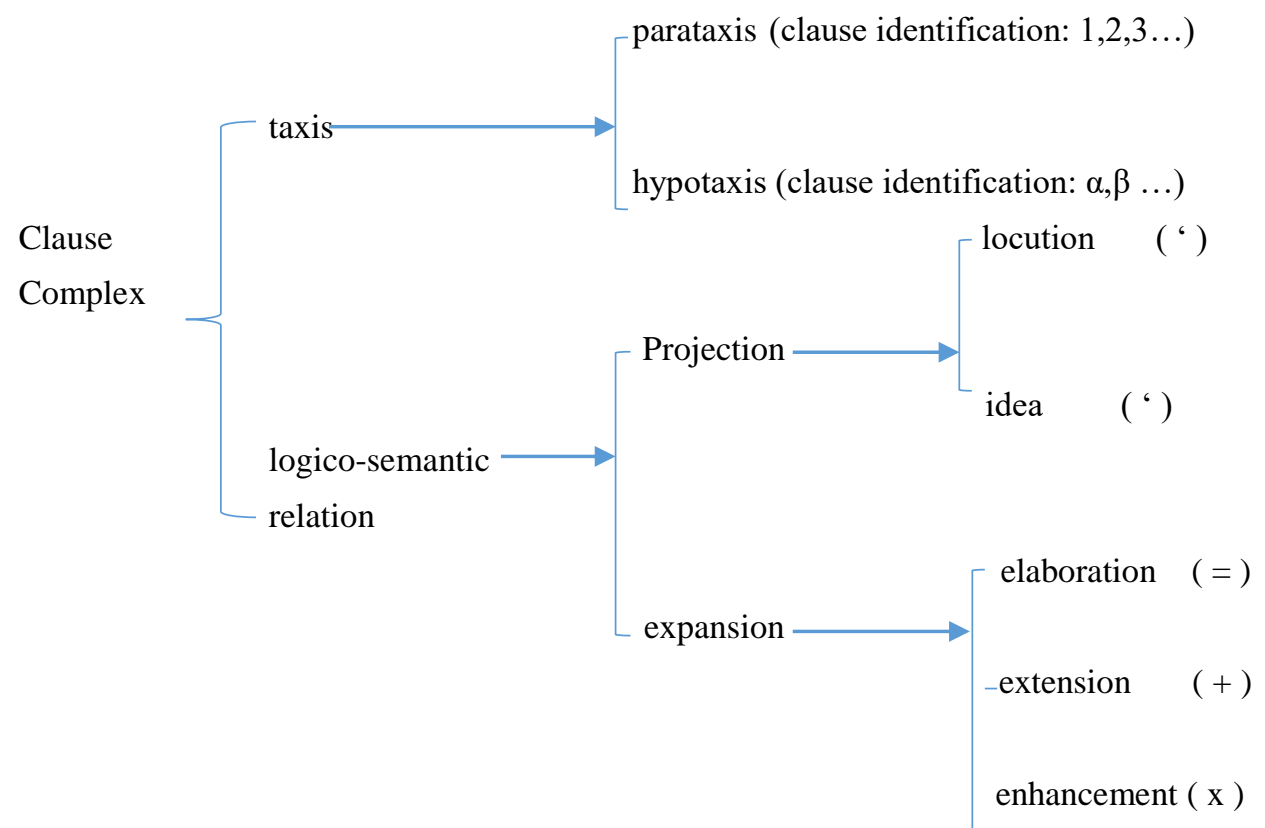

Figure 1. The system of clause complex in English

The system of taxis contains the choices of interdependency relationship between clauses linked together to form a clause complex. Linking or clustering of clauses together is done paratactically when the clauses are of equal semantic and functional status (being semantically and structurally independent) as in the clause complexes: At home he helped her up the stairs and he lay down (excerpted from Joyce Carol Oates' The Lady with the Pet Dog) and A great burst of cheering and laughter rose from the Tory benches and our supporters in the spectators' galleries roared with out-oforder jubilation (excerpted from Margaret Thatcher's The Downing Street Years) separately analysed below.

1. At home he helped her up the stairs and he lay down.

\begin{tabular}{|c|c|c|c|c|}
\hline|| $\mid$ At home & he & helped & her & up the stairs $\|$ \\
\hline $\mathbf{A}_{\mathbf{1}}$ & $\mathbf{S}$ & $\mathbf{P}$ & $\mathbf{C}$ & $\mathbf{A}_{\mathbf{2}}$ \\
\hline \multicolumn{6}{|c|}{ Clause 1 } \\
\hline and & he & lay & down $\|$ \\
\hline & S & P & A \\
\hline
\end{tabular}

2. A great burst of cheering and laughter rose from the Tory benches and our supporters in the spectators' galleries roared with out-of-order jubilation.

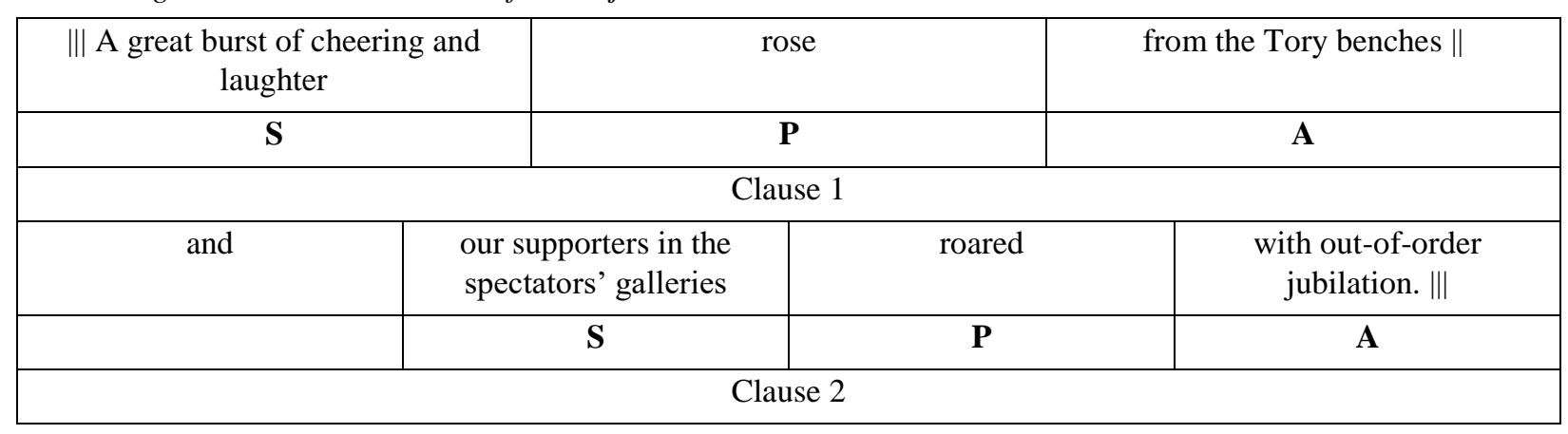


Each of the two clause complexes above contains two semantically and structurally independent clauses, both linked together by 'and'. Other words used to link clauses of this type to form clause complexes are but and or, the trio referred to as linking conjunctions or linkers (Bloor and Bloor, 2004: p.184).

On the other hand, linking of clauses together to form a clause complex is done hypotactically when the clauses are of unequal semantic and functional status (one or more clauses being semantically and structurally dependent on one or more independent clauses) as in the clause complexes: Dark girls, fair girls were patting their hair, trying ribbons again, tucking handkerchiefs down the front of their bodices, smoothing marble-white gloves (excerpted from Katherine Mansfield's Her First Ball); and I was disappointed, for in the pictorial sense I had immediately seen them (excerpted from Henry James' The Real Thing), analysed below.

3. Dark girls, fair girls were patting their hair, trying ribbons again, tucking handkerchiefs down the front of their bodices, smoothing marble-white gloves.

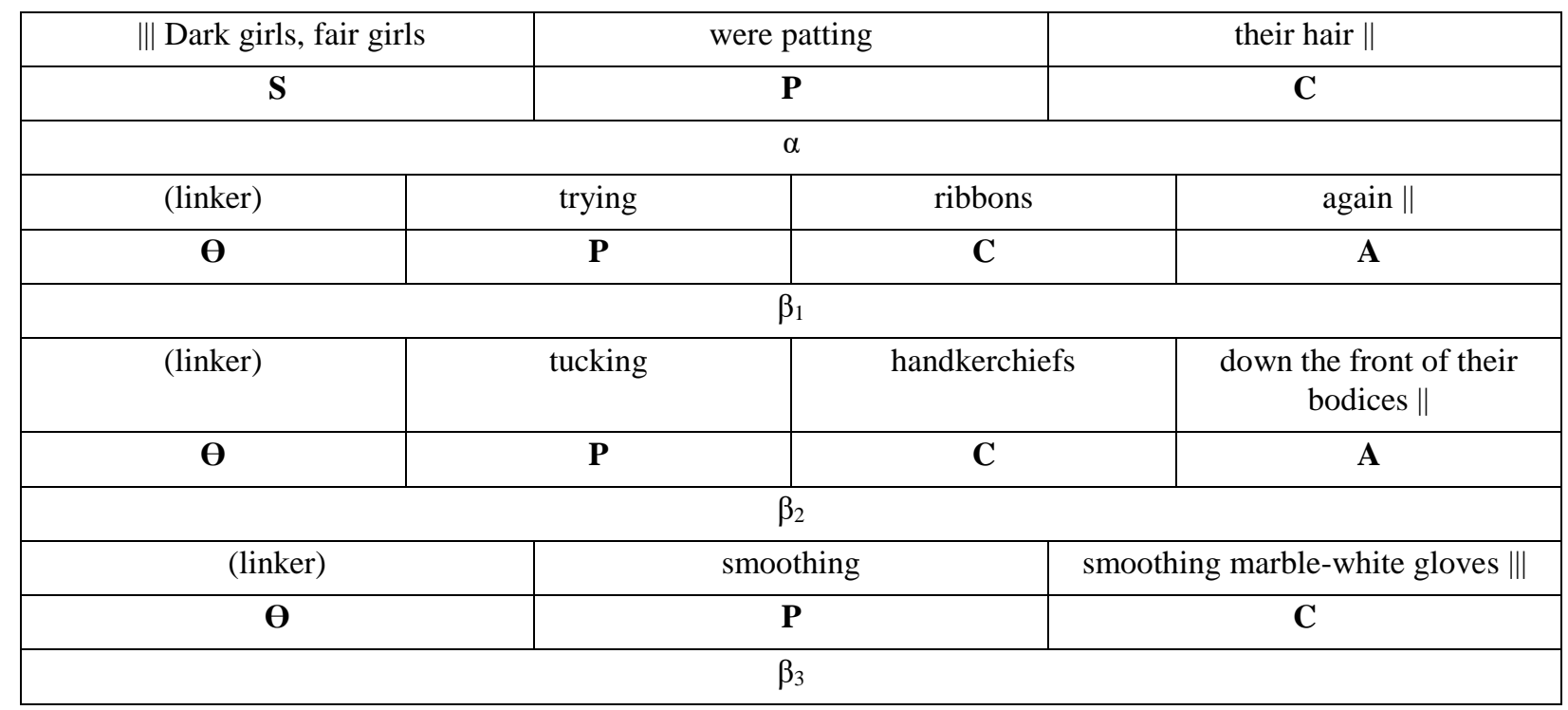

4. I was disappointed, for in the pictorial sense I had immediately seen them.

\begin{tabular}{|c|c|c|c|c|c|c|}
\hline \multicolumn{2}{|r|}{$\||| I$} & \multicolumn{3}{|c|}{ was } & \multicolumn{2}{|c|}{ disappointed \| } \\
\hline & $\mathbf{S}$ & \multicolumn{3}{|c|}{$\mathbf{P}$} & \multicolumn{2}{|c|}{$\mathbf{C}$} \\
\hline \multicolumn{7}{|c|}{$\alpha$} \\
\hline \multirow[t]{2}{*}{ For } & $\begin{array}{l}\text { in the pictorial } \\
\text { sense }\end{array}$ & I & had & immediately & seen & them $\| \mid$ \\
\hline & $\mathbf{A}_{1}$ & $\mathbf{S}$ & & $\mathbf{A}_{2}$ & $\mathbf{P}$ & C \\
\hline \multicolumn{7}{|c|}{$\beta$} \\
\hline
\end{tabular}

The clause complex 3 above comprises 4 clauses, one of which is the main or independent clause $(\alpha)$ and the other $3\left(\beta_{1}\right.$, $\beta_{2}$ and $\beta_{3}$ ) being clauses that depend on the independent clause $(\alpha)$ to make complete meaning. Here, the linking of the clauses is done with the use of comma rather than overt linkers. In clause complex 4, there are 2 clauses: $(\alpha)$ being the independent clause and $(\beta)$ being the dependent one.

The logicosemantic system has to do with choices that arise as a result of 'the specific type of meaning relationship between linked clauses' (Eggins, 2004: p.259). The two main options here (Fig. 1) are projection (where a clause is reported in another clause) and expansion (where one clause is a further development of another one in the clause complex). Projection has two sub-options (locution and idea), while expansion has three sub-options (elaboration, extension and enhancement).

Halliday and Matthiessen (2014) further distinguish embedded clauses from paratactic and hypotactic clauses. They maintain (p.491) that while parataxis and hypotaxis are relations between two or more clauses in a clause complex, embedding is 'a semogenic mechanism' whereby a clause is made to function as a constituent within the structure of a group, and there is no direct relationship between an embedded clause and the clause within which it functions. This differentiation is exemplified in the sentence The students whose results were seized were the culprits, that have always terrorized the campus. 


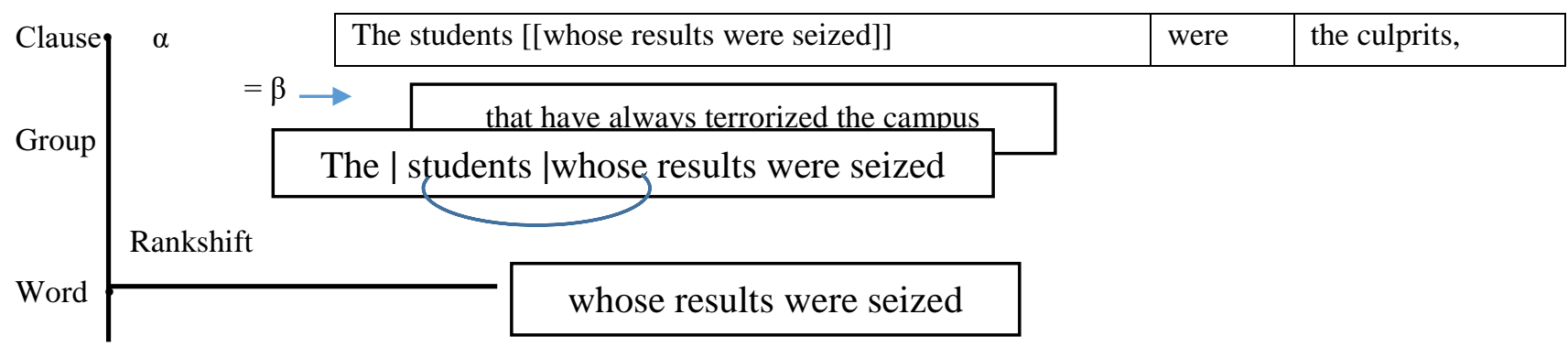

Figure 2. Rankshifted/embedded clauses vs. hypotactically linked clauses within a clause complex

The example above is a clause complex comprising two clauses: one main $(\alpha)$ clause The students whose results were seized were the culprits, and one dependent $(\beta)$ clause that have always terrorized the campus. The Subject of the main clause (The students whose results were seized), however, is a nominal group within which the clause whose results were seized has been rankshifted and embedded as postmodifier to students. The rankshifted clause has no syntactic and direct semantic relationship with the linked clause. This is an embedded clause. Embedded clauses are used to expand the meaning of the anteceding noun (Head) in a nominal group; as constituting a nominal group itself and as postmodifier in an adverb group with respective examples from the study data as shown below.

1. On this occasion, the two Torries walked towards the Speaker's left hand in the space [[usually occupied by government whips]].

2. From the beginning, I believed [[whatever I was told $]]$

3. She was very slow [[in getting herself pregnant again $]]$.

\section{Research Methodology}

The study is a textual analysis of selected prose-works of male and female writers with the aim of determining whether there are (or not) grammar related variation in language use. In all, a total of ten prose pieces were selected for the study, five being male-authored and another five being female-authored. Four of the texts in each category (maleauthored and female-authored) were fiction pieces, while an autobiography was selected for each category to make the fifth (Mahatma K. Ghandi's The Story of My Experiments with Truth - Autobiography for male-authored, and Margaret Thatcher's The Downing Street Years - Autobiography for the female-authored). The selected texts are listed below.

Table 1. Prose-works selected as research data

\begin{tabular}{lll}
\hline S/N & Male-authored texts & Female-authored texts \\
\hline 1. & Henry James' The Real Thing & Katherine Mansfield's Her First Ball \\
\hline 2. & Salman Rushdie's The Prophet's Hair & Joyce Carol Oates's The Lady with the Pet Dog \\
\hline $3 . \quad$ John Cheever's The Country Husband & Sefi Atta's Everything Good Will Come \\
\hline 4. & Jorge Luis Borges' The Garden of Forking Paths & Emecheta's The Bride Price \\
\hline 5. & $\begin{array}{l}\text { Mahatma K. Ghandi's The Story of My Experiments } \\
\text { with Truth - Autobiography }\end{array}$ & $\begin{array}{l}\text { Margaret Thatcher's The Downing Street Years - } \\
\text { Autobiography }\end{array}$ \\
\hline
\end{tabular}

The analytical framework adopted was the Hallidayan Systemic Functional Grammar, with specific emphasis on the grammar of logical meaning. The focus of the study was on the structuring and organization of clauses to make logicosemantic sense. The major pre-occupation was therefore a close examination and analysis of the clauses in the selected texts. In each of the ten texts, the first fifty sentences of the introductory section were excised as data for analysis, altogether making 500 sentences (250 for male-authored, 250 for female-authored texts). The analysis was aimed at identifying all constituent clauses in the data; distinguishing clause complexes from clause simplexes; identifying the interdependency and meaning relations among linked clauses; and distinguishing embedded clauses from linked clauses. The analysis was done using Halliday and Matthiessen (2014) and Eggins, (2004) procedures and notations. Four excerpts from four of the selected prose-works (two female-authored, two male-authored) used as data for the study are analysed below as examples. 
Excerpt one: (female writer) Katherine Mansfield's Her First Ball

\begin{tabular}{|c|c|c|}
\hline Clause complex & $x \beta$ & (1i)Exactly when the ball began \\
\hline & $\alpha$ & (1ii)Lella would have found it hard to say. \\
\hline Clause simplex & & (2) Perhaps her first real partner was the cab. \\
\hline Clause simplex & & $\begin{array}{l}\text { (3) It did not matter [[that she shared the cab with the Sheridan girls and their } \\
\text { brother]] }\end{array}$ \\
\hline Clause simplex & & (4) She sat back in her own little corner of it. \\
\hline Clause simplex & & $\begin{array}{l}\text { (5) The bolster [[on which her hand rested]] felt like the sleeve of an unknown young } \\
\text { man's dress suit. }\end{array}$ \\
\hline
\end{tabular}

Clause simplex (6) And away they bowled, past waltzing lampposts and houses and fences and trees.

In the excerpt above, there are six sentences (marked $1-6)$. Of these, there is only one clause complex (1), comprising (1i) a dependent clause (of expansion - enhancement) Exactly when the ball began and (1ii) an independent clause Lella would have found it hard to say. The other five sentences are clause simplexes in each case, except that clause simplexes (3) and (5) each contains an embedded clause: that she shared the cab with the Sheridan girls and their brother as the Complement in (3), and on which her hand rested as post-modifier in the Subject of (5).

Excerpt two: $\quad$ (Female writer) Margaret Thatcher's The Downing Street Years (pp. 3-4)

Clause simplex

Clause simplex

Clause simplex

Clause complex

Clause simplex

Clause simplex

Clause simplex
(1) The wait before the announcement was filled with rumour and counter-rumour across the Chamber.

(2)It seemed endless.

(3) Our Chief Whip quietly gave me his own forecast.

$1 \alpha \quad{ }_{(4 i)}$ I said nothing

+2 $\alpha \quad$ (4ii) and tried to look inscrutable, doubtless without success.

(5)Some on the Labour benches, [[hearing of Mr. Maguire's appearance]], began to grin in anticipation of victory

${ }_{(6)}$ But Mr. Maguire had arrived only to abstain.

(7) And on 28 March 1979, James Challaghan's Labour Government, the last Labour Government, and perhaps the last ever, fell from office.

In excerpt two above, there are seven sentences $(1-7)$. Of these, there is only one clause complex (4), with (4i) and (4ii) paratactically linked together with the linker and, because each clause is independent in status. All other six sentences are simplexes, and only sentence (5) contains an embedded clause hearing of Mr. Maguire's appearance.

\section{Excerpt three: (Male writer) Salman Rushdie's The Prophet's Hair}

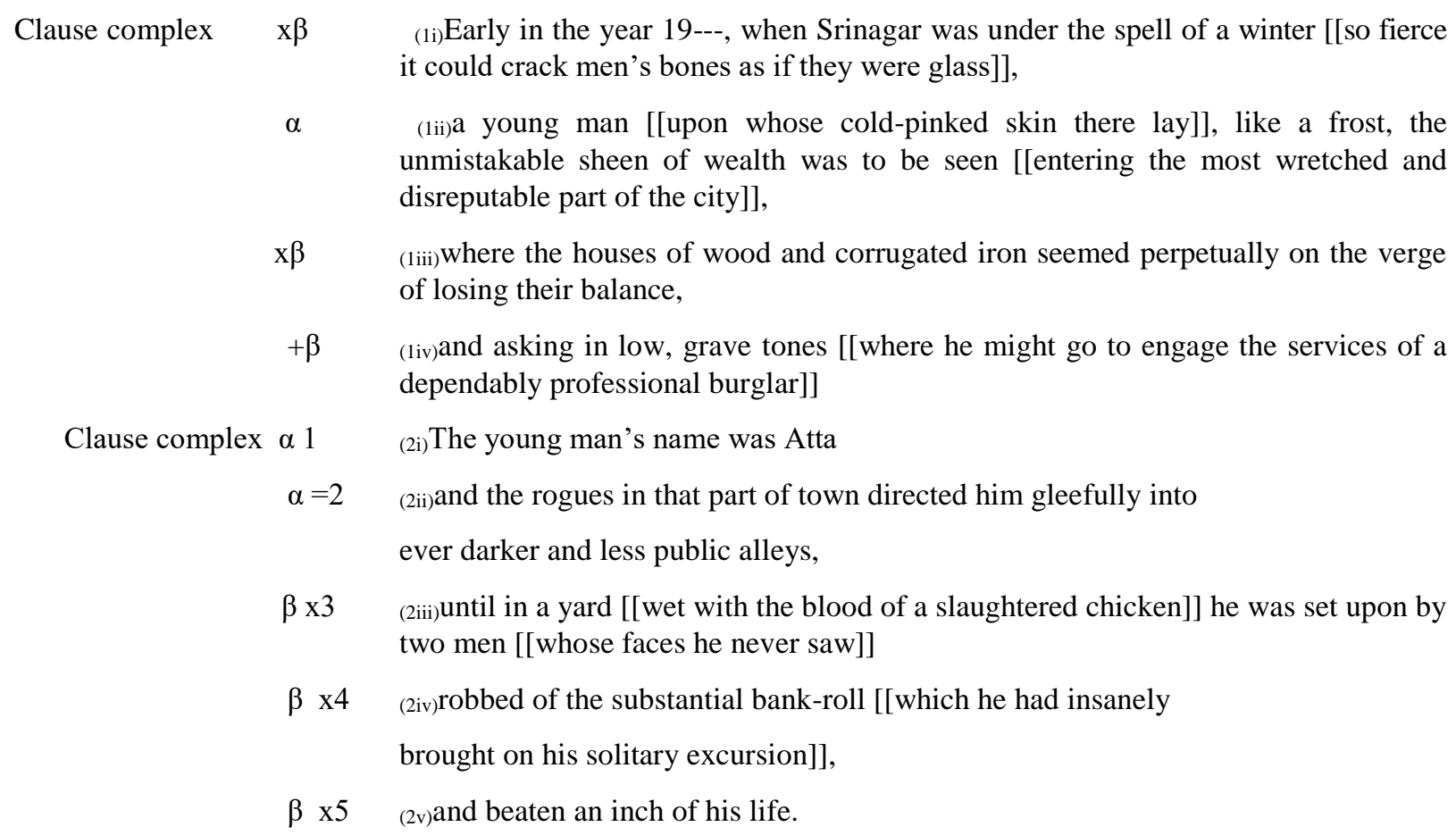


In excerpt three above, there are only two sentences. Each of the two sentences is a clause complex. Clause complex 1 has four constituent clauses linked together. Clause (1i) is a dependent clause $(\beta)$ and a clause of expansion (showing relationship of enhancement); clause (1ii) is an independent clause $(\alpha)$ on which all other clauses depend and to which they are linked; clauses (1iii) and (1iv) are also dependent clauses, each being a clause of expansion: (1iii) showing relationship of enhancement while (1iv) shows relationship of extension. The interdependency relationship among these clauses is hypotactic since they are not of equal status. Clause complex (2) has five clauses: (2i) and (2ii) are each independent and are paratactically linked with the linker and. Clauses (2iii), (2iv) and (2v) are all dependent clauses, each being clauses of expansion, showing relationship of enhancement. There are seven instances of embedding in the excerpt: four in clause complex 1 and three in clause complex 2.

\section{Excerpt Four: $\quad$ Mahatma. K. Ghandi's The Story of My Experiments with Truth - Autobiography}

\begin{tabular}{|c|c|c|}
\hline Clause simplex & & $\begin{array}{l}\text { (1) Four or five years ago, at the instance of some of my dearest } \\
\text { to write my autobiography. }\end{array}$ \\
\hline Clause Complex & $\alpha$ & (2i) $I$ made the start \\
\hline & $\alpha$ & (2ii) but scarcely had I turned over the first sheet \\
\hline & $x \beta$ & (2iii) When riots broke out in Bombay \\
\hline & $\alpha$ & (2iv) and the work remained at a standstill \\
\hline Clause simplex & & $\begin{array}{l}\text { (3) Then followed a series of events [[which culminated in } \\
\text { Yeravda]] }\end{array}$ \\
\hline Clause complex & $\alpha$ & (4i)Sjt. Jeramdas, [[who was one of my fellow prisoners there $]$, \\
\hline & & asked me \\
\hline & ' $\beta$ & (4ii)to put everything else on one side \\
\hline & ' $\beta$ & (4iii) and finish writing the autobiography \\
\hline
\end{tabular}

In excerpt four, there are four sentences, two (1 and 3) being clause simplexes and two (2 and 4) being clause complexes. In (2), there are four constituent clauses $\left(2_{\mathrm{i}}-2_{\mathrm{iv}}\right)$ making the clause complex. Clause $\left(2_{\mathrm{i}}\right)$ is the main clause to which other dependent clauses have been hypotactically linked. Clause (4) also comprises three different clauses $\left(4{ }_{i}\right.$ $\left.-4_{\text {iii }}\right)$ with $\left(4_{\mathrm{i}}\right)$ being the main clause, to which $\left(4_{\mathrm{ii}}\right.$ and $4_{\mathrm{iii}}$, both being dependent clauses) have been hypotactically linked. There are two instances of embedding in the excerpt: one in simplex 3 and the other in clause complex 4(i).

At the end of the analyses of every 50 sentences per text, the comparative frequencies of each clause type (clause complexes, clause simplexes and embedded clauses) were determined first per selected text, and then per text type (male-authored and female-authored), thus constituting the results of analyses and research findings.

\section{Results and Discussion}

Table 1 below shows the frequencies of each of clause complexes, clause simplexes and embedded clauses in each 50 sentences analysed per selected text. In terms of clause simplexes across texts, the frequencies are higher in each of the female-authored texts $(27,27,27,33$ and 26 out of 50 sentences each) than male-authored texts $(19,18,6,11$ and 18 out of 50 sentences each). These show a total of 140 clause simplexes (out of $250,56 \%$ ) for female-authored texts and $72(28.8 \%)$ for male-authored texts. This means for the female-authored texts, clause simplexes are more than half of the 50 sentences in each case, while for male-authored texts, clause simplexes are less than half of the 50 sentences in each case.

In terms of clause complexes across texts, the frequencies are higher in male-authored texts $(31,32,44,39$ and 32 out of 50 sentences each) than female-authored texts $(23,23,23,17$ and 24 out of 50 sentences). In all, there are 178 clause complexes (out of 250 sentences), representing $71.2 \%$, in the male-authored texts, whereas the total frequency of clause complexes in female-authored texts is 110 (out of 250 sentences), and representing 44\%. This means for the maleauthored texts, clause complexes are more than half of the total sentences in each text, whereas in female authored texts, clause complexes are less than half of the total sentences per text.

Embedded clauses were found in both clause simplexes and complexes across texts. In terms of text-specific frequencies, the highest frequencies were recorded in male-authored (51 and 29, then 21, 15 and 13), while the femaleauthored texts have 27, 26, 22, 9 and 3 as frequencies. In all, a total of 129 embedded clauses were found in the maleauthored and 87 in female-authored texts. The statistical and graphical presentations of these are shown in Table 1 and Fig. 2. 
Table 2. Frequencies of clause simplexes, complexes and embedded

\begin{tabular}{|c|c|c|c|c|c|c|}
\hline $\mathbf{S} / \mathbf{N}$ & Texts & $\begin{array}{l}\text { No. of } \\
\text { sentences }\end{array}$ & $\begin{array}{l}\text { Clause } \\
\text { simplexes }\end{array}$ & $\begin{array}{l}\text { Clause } \\
\text { complexes }\end{array}$ & $\begin{array}{l}\text { Total clauses in } \\
\text { clause complexes }\end{array}$ & Embedded clauses \\
\hline \multicolumn{7}{|c|}{ Male authored texts } \\
\hline 1. & $\begin{array}{l}\text { The Garden of } \\
\text { Forking Paths }\end{array}$ & 50 & 19 & 31 & 84 & 13 \\
\hline 2. & $\begin{array}{l}\text { The Country } \\
\text { Husband }\end{array}$ & 50 & 18 & 32 & 80 & 15 \\
\hline 3. & The Real Thing & 50 & 6 & 44 & 131 & 29 \\
\hline 4. & The Prophet's Hair & 50 & 11 & 39 & 163 & 51 \\
\hline 5. & $\begin{array}{l}\text { The Story of My } \\
\text { Experiments with } \\
\text { Truth }\end{array}$ & 50 & 18 & 32 & 88 & 21 \\
\hline & Total & 250 & 72 & 178 & 546 & 129 \\
\hline \multicolumn{7}{|c|}{ Female authored texts } \\
\hline 6. & Her First Ball & 50 & 27 & 23 & 85 & 9 \\
\hline 7. & $\begin{array}{l}\text { The Lady with The } \\
\text { Pet Dog }\end{array}$ & 50 & 27 & 23 & 79 & 3 \\
\hline 8. & $\begin{array}{l}\text { Everything Good } \\
\text { Will Come }\end{array}$ & 50 & 27 & 23 & 78 & 22 \\
\hline 9. & The Bride Price & 50 & 33 & 17 & 98 & 26 \\
\hline 10. & $\begin{array}{l}\text { The Downing } \\
\text { Street Years }\end{array}$ & 50 & 26 & 24 & 69 & 27 \\
\hline & Total & 250 & 140 & 110 & 409 & 87 \\
\hline
\end{tabular}

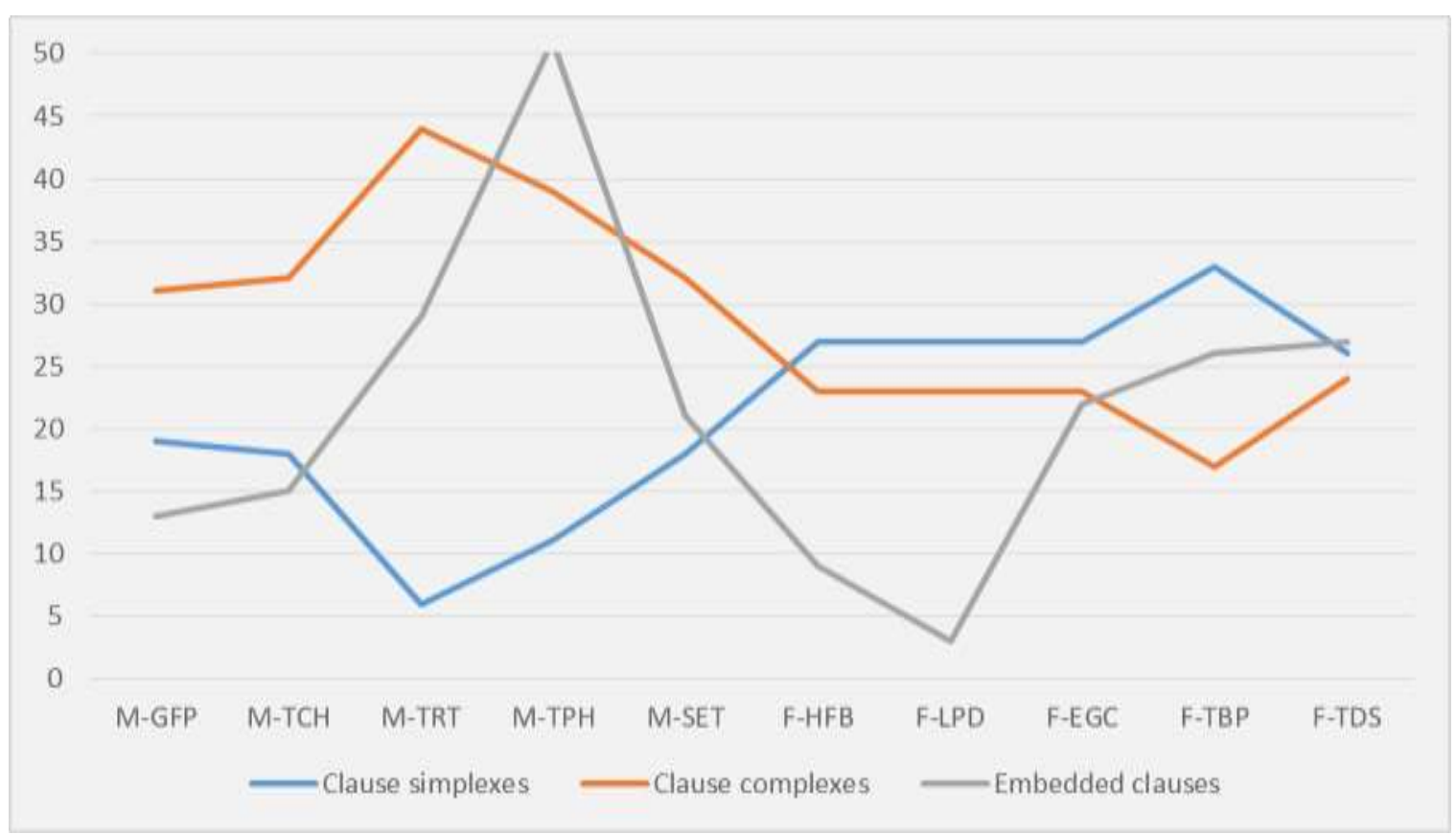

Figure 3. Frequencies of clause simplexes, clause complexes and embedded clauses across texts

Keys:

M-GFP - $\quad$ The Garden of Forking Paths (Male-authored)

M-TCH - The Country Husband (Male-authored)

M-TRT - The Real Thing (Male-authored)

M-TPH - The Prophet's Hair (Male-authored)

$\mathrm{M}-\mathrm{TPH} \quad$ - $\quad$ The Story of My Experiments with Truth (Male-authored)

F-HFB - Her First Ball (Female-authored)

F-LPD - The Lady with The Pet Dog (Female-authored)

F-EGC - Everything Good Will Come (Female-authored)

F-TBP - The Bride Price (Female-authored)

F-TDS - The Downing Street Years (Female-authored) 
In this study, the results have shown significant variation in grammatical choices on account of gender based on the three parameters and variables investigated. The results have shown that male authors show preference for clause clustering in conveying their narrative thoughts, which is evident in the fact that more than half of the 50 sentences analysed per text were clause complexes. This is opposite in female authors, who show preference for simplexes in their narratives, as evident in the frequencies of such, which were more than half of the 50 sentences analysed per text. Male authors have also been identified to have more frequencies of embedded clauses than female authors as shown in the 129 (male) and 87 (female) recorded.

The two autobiographies chosen for the study (one male authored and the other female authored) have further confirmed the results of analyses. Mahatma K. Ghandi's The Story of My Experiments with Truth - Autobiography (male-authored) showed a high frequency of clause complexes (64\%, and being more than half of total sentences) like all other male-authored texts, while Margaret Thatcher's The Downing Street Years shows a markedly low preference for clause complexes (48\%, and being less than half of total sentences). The implication of the foregoing results is that male authors evidently choose to integrate and organize meanings of various but related sorts into clauses, thus making the clauses both semantically and syntactically complex. On the other hand, female authors, as shown in the study, evidently choose to organize meanings into simple clause structures, thus making their clauses semantically and syntactically simple.

A clause is regarded as syntactically and semantically complex in the study when that clause contains more than one clause structure (Subject, Predicator, Complement and Adjunct - SPCA) and more than one instance of rankshifted or embedded clause, both being caused by semantic expansion. The following clause (excerpted from Sefi Atta's Everything Good Will Come) exemplifies this.

He was usually there in the dry season which lasted most of the year, scarcely in the chilly harmattan which straddled Christmas and New Year, and never in the swampy rainy season that made our veranda floor slippery over the summer vacation.

This is a clause complex having three component clauses if interpreted and analysed, bearing in mind the elliptic instances of the Subject and Predicator (He was of clause 1) in clauses 2 and 3:

Table 3a. Structural analysis of a clause showing syntactic complexity

\begin{tabular}{lccl}
\hline Clause 1 & He & was & $\begin{array}{l}\text { usually there in the dry season [[which (S) lasted (P) } \\
\text { most of the year (A)]] }\end{array}$ \\
& & & A
\end{tabular}

Table 3b. Structural analysis of nominal groups with rankshifted clauses (within a clause complex)

\begin{tabular}{|c|c|c|c|c|c|c|c|c|}
\hline \multirow{3}{*}{$\begin{array}{l}\text { Nom. } \\
\text { Group } 1\end{array}$} & the & dry & & season & & which & lasted & most of the year \\
\hline & & & & & & \multicolumn{3}{|c|}{ Postmodifier (Rankshifted clause: defining relative) } \\
\hline & Modifier $\beta$ & Modifier $\beta$ & & Head $\alpha$ & & Subject & Predicator & Adjunct \\
\hline \multirow[t]{3}{*}{$\begin{array}{l}\text { Nom. } \\
\text { Group } 2 .\end{array}$} & The & chilly & & harmattan & & which & straddled & $\begin{array}{l}\text { Christmas and New } \\
\text { Year }\end{array}$ \\
\hline & & & & & & \multicolumn{3}{|c|}{ Postmodifier (Rankshifted clause: defining relative) } \\
\hline & Modifier $\beta$ & Modifier $\beta$ & & Head $\alpha$ & & Subject & Predicator & Complement \\
\hline \multirow[t]{3}{*}{$\begin{array}{l}\text { Nom. } \\
\text { Group } 3\end{array}$} & The & swampy & rainy & season & that & made & $\begin{array}{l}\text { our veranda } \\
\text { floor }\end{array}$ & $\begin{array}{ll}\text { slippery } & \text { over the } \\
& \text { summer } \\
& \text { vacation }\end{array}$ \\
\hline & & & & & \multicolumn{4}{|c|}{ Postmodifier (Rankshifted clause, defining relative) } \\
\hline & Modifier $\beta$ & Modifier $\beta$ & Modifier $\beta$ & Head $\alpha$ & Subject & Pred. & Comp. 1 & Comp. 2 \\
\hline
\end{tabular}

In the clause complex example above, each of the three component clauses has its clause structure (SPA) structure. The Adjunct element of each clause also contains a nominal group, which extends the meaning of the anteceding noun, and 
which has its own independent clause structure (SPA, SPC and SPCA respectively). The different clausal structures and semantic units integrated in each clause making up the clause complex therefore results in some complexity.

The major finding of this study (that is, identification of variation in language use on account of gender) corroborates the findings of some of the earlier studies including Lakoff (1975), reverberated by Coates (1986), which reported that women use many linguistic forms such as hesitation, intensifiers, qualifiers, tag questions etc. which weaken or mitigate the force of their utterance compared to men; and Holmes (1990), Zimmerman and West (1975), which suggested that there were definite and patterned ways in which men exercise the power and dominance they enjoy in other contexts in conversations with women. The finding also correlates with the findings of some previous studies particularly concerning variation in grammatical and lexical choices on account of gender. For example, Oliva and Serrano (2016) investigated the relationship between the statistical patterning of linguistic choices across genders and the meaningful use of such elements in particular contexts, and it was found that male discourse usually shows higher rates of expressed subject pronouns, while women are more inclined to omission. They also reported identified differences in male and female preference for particular grammatical subjects, with men promoting the use of the singular first person and women, that of the second one. This current study and the emanating findings are particularly significant because the texts used as data were authored by people from different linguistic backgrounds, some having English as first language (Margaret Thatcher, Henry James, Katherine Mansfield etc.) and others having English as second language (Mahatma Ghandi, Sefi Atta, and Buchi Emecheta). The study was also not limited to only one prose-genre, as it involved fiction (short stories) and autobiographies.

\section{Conclusion}

Humans, male and female, use language for the same endless communicative purposes and objectives. However, as some previous studies have found out, there could be lexical, syntactic and pragmatic variations in the use of language with users' gender, among other factors, as variable. This study set out to investigate whether (or not) there are variations in the use of language by male and female writers using the prose-works of selected male and female authors. The focus of the study is on the organization of meanings into clauses with specific reference to the notions of clause complexes and embedded clauses (an aspect of SFG's grammar of logical meaning). This entails the analysis of the sentence data into clause simplexes, clause complexes and embedded clauses, and the determination of the frequencies of each. It was found, with the result of analyses, that male authors integrate and organize meanings into clause complexes more than simplexes, and that female writers use more of clause simplexes than clause complexes. It was also found that male authors used more of embedded clauses than female authors, with the overall implication that the language of male authors tends to be more syntactically and semantically complex than that of female authors.

\section{References}

Atta, S. (2006). Everything good will come. Lagos, Nigeria: Farafina, 11-15.

Bloor, T. \& Bloor, M. (2013). The functional analysis of English (3rd ed.). London, England: Routledge.

Borges, J. L. (2002). The garden of forking paths. In Hunter, P., Booth, H. and Mays, K. (eds.) The Norton Introduction to Literature ( $8^{\text {th }}$ ed.). New York, NY: W. W. Norton \& Company, 734-736.

Cameron, O. (1985). Feminism and linguistic theory. London, England: MacMillan.

Cameron, O. (1988). Introduction. In Jennifer, C. and Cameron, D. (eds.) Women in their speech communities: New perspectives in language and sex. London, England: Longman, 74-93.

Cheever, J. (2002). The country husband. In Hunter, P., Booth, H. and Mays, K. (eds.) The Norton Introduction to Literature, $8^{\text {th }}$ edition. New York, NY: W. W. Norton \& Company, pp. 23-40.

Coates, J. (2013). Women, men and language (3rd ed.). Oxon, England: Routledge.

Eggins, S. (2013). An introduction to Systemic Functional Linguistics (2nd ed.). London, England: Bloomsbury.

Emecheta, B. (1975). The bride price. London, England: Allison \& Busby George Braziller, 1-6.

Farinde, R. (2009). Issues in gender and discourse. In Language, Gender and Politics (A festschrift for Yisa Kehinde Yusuf). Lagos, Nigeria: Concept Publications, 23-32.

Gandhi, M. K. (1927). The story of my experiments with truth. (Translated by Mahadev, Desai). Ahmedabad, India: Navajivan Publishing House, xi - xiii.

Halliday, M. A. K. \& Matthiessen, C. M. I. M. (2014). Introduction to functional grammar (4th ed.). London, England: Routledge.

Holmes, J. (1984). Women's language: A functional approach. General Linguistics 24(3), 149-178.

Holmes, J. (1990). Hedges and booster in women and men's speech. Language and Communication. 10(3): 185-205.

James, H. (2002). The real thing. In Hunter, P., Booth, H. and Mays, K. (eds.) The Norton Introduction to Literature, ( $8^{\text {th }}$ ed.). New York, NY: W. W. Norton \& Company, 655-672.

Kendall, S. \& Tannen, D, (2003). Discourse and gender. In Schiffrin, D., Tannen, D. and Hamilton, H. E. (eds.) The handbook of discourse analysis. London, England: Blackwell Publishing, 281-312.

Lakoff, R. (1975). Language and women's place. New York, NY: Harper and Row. 
Mansfield, K. (2002). Her first ball. In Hunter, P., Booth, H. and Mays, K. (eds.) The Norton Introduction to Literature, ( $8^{\text {th }}$ ed.). New York, NY: W. W. Norton \& Company, 720-724.

Oates, J. C. (2002). The lady with the pet dog. In Hunter, P., Booth, H. and Mays, K. (eds.) The Norton Introduction to Literature, ( $8^{\text {th }}$ ed.). New York, NY: W. W. Norton \& Company, pp. 748-760.

O’Barr, W. \& Atkin, B. (1978). Women's language or powerless language. In Coates, J. (ed.), Language and Gender: A Reader. Oxford, England: Blackwell, 377-87.

Oliva, M. A. A. \& Serrano, M. J. (2016). A matter of style: Gender and subject variation in Spanish. Gender and Language, Vol. 10(2), DOI: 10.1558/genl.v10i2.18325. Retrieved from: https://journals.equinoxpub.com/index.php/GL/article/view/18325

Rushdie, S. (2002). The prophet's hair. In Hunter, P., Booth, H. and Mays, K. (eds.) The Norton Introduction to Literature, ( ${ }^{\text {th }}$ ed.). New York, NY: W. W. Norton \& Company, pp. 790-800.

Tannen, D. (1994). Gender and discourse. Oxford, England: Oxford University Press.

Tannen, D. (2003). The relativity of linguistic strategies: Rethinking power and solidarity in gender dominance. In Paulson, C. B. and Tucker, G. R. (eds.) Sociolinguistics: The Essential Readings. Malden, MA: Blackwell Publishing, 208-229.

Thatcher, M. (1993). The Downing street years. London, England: HarperCollins Publishers (pp. 3 - 5).

West, C., Lazar, M. M., \& Kramarae, C. (1997). Gender in discourse. In van Dijk, Teun (ed.) Discourse as Social Interaction. London, England: Sage Publications, pp. 119-205.

Zimmerman, D. \& West, C. (1975). Sex role interpretations and silences in conversation. In Thorne, Barrie and Hensely, (eds.) Language and Sex: Difference and Dominance. Rowly, Nancy M.A. Newbury Home, 105-2. 